\title{
Correlations between daily weight gain, lipid peroxidation and glutathione status of liver and kidney in different pig genotypes
}

\author{
Krisztián Balogh'², Mária Weber³, Mónika Heincinger², Györgyi Kollár² and Miklós \\ Mézes $^{2}$
}

${ }^{1}$ Research Group of Animal Breeding and Hygiene, Faculty of Animal Science, University of Kaposvár, Kaposvár, Hungary, ${ }^{2}$ Department of Nutrition, Szent István University, Gödöllö, Hungary, ${ }^{3}$ Department of Pig and Small Animal Breeding, Szent István University, Gödöllő, Hungary

\begin{abstract}
Four pig hybrids (Pannon, Hungahib-39, Középtiszai and Dalland) were fattened up to $100 \pm 2 \mathrm{~kg}$ body weight. Feed intake and body weight were measured and daily weight gain was calculated. Malondialdehyde (MDA) and reduced glutathione (GSH) content, and glutathione peroxidase (GPx) activity were measured in liver and kidney. Daily weight gain was significantly lower in Pannon and Hungahib-39 hybrids. Amount of MDA was significantly higher in the liver of the hybrids with higher daily weight gain, and similar tendency was found in kidney. GSH content of liver did not differ significantly among the hybrids. The kidney of the Középtiszai hybrid had significantly lower GSH concentration than the others. GPx activity was the lowest in liver and kidney of Középtiszai hybrid. There was no significant correlation between daily weight gain and MDA content in liver, but positive correlation was found in the kidney of Pannon and Hungahib-39 hybrids. Daily weight gain showed significant correlation with GSH content of liver of Középtiszai hybrid. Between daily weight gain and GPx activity negative correlations were found in all hybrids and tissues, but none of them was significant. GSH content showed negative significant correlation with MDA content of liver of Középtiszai and in kidney of Pannon hybrid. Correlation between GSH content and GPx activity was positive and significant in the liver and kidney of Pannon hybrid. The results showed that different daily weight gain of pig hybrids has effect on the lipid peroxide and glutathione status of liver and kidney.
\end{abstract}

Keywords: pig, daily weight gain, genotype, reduced glutathione, glutathione peroxidase, malondialdehyde

\section{Introduction}

Lipid peroxidation and cellular antioxidant defence, including reduced glutathione content and glutathione-peroxidase activity, have importance in the oxidative stability of pork (Krska et al. 2001), because glutathione peroxidase reduces hydrogen peroxide and lipid hydroperoxides, potentially harmful pro-oxidants that may promote peroxidation of polyunsaturated phospholipids in biological membranes. Importance of reduced glutathione is supported by those findings that the magnitude of muscle protein turnover depends on, 
among other factors, the actual glutathione supply (Śliwa-Jóźwik et al. 2002). Additionally the glutathione peroxidase 5 gene (GPX5) on SSC7 is located in a chromosomal region in which several quantitative trait loci (QTL) for reproductive traits in swine, such as uterine capacity, ovulation rate and litter size have been detected. Linkage analyses of GPX5 showed that this gene is closely linked to the major histocompatibility complex (MHC), which has been suggested to have an effect on reproductive traits in swine (Vaiman et al. 1998). However, there was no significant association between different GPX5 genotypes with litter size in a commercial pig cross population (Buske et al. 2006). There were several investigations during the last decades on the genetic differences in the amount and/or activity of the glutathione redox system, in particular glutathione peroxidase (GPx) activity. Significant differences were found in some farm animal species such as poultry (Shaaban et al. 2004); goose (Mézes et al. 1989); rabbit (Virág et al. 1996); sheep (Atroshi et al. 1981); goat (Fidanci et al. 2001); cattle (Wachter et al. 1999) and pig (Lingaas et al. 1991). There are also some data about the correlation between glutathione peroxidase activity and some production traits such as weight gain in poultry (Shaaban et al. 2004) and sheep (Atroshi et al. 1981), carcass weight and percent of edible tissues in rabbit (Virág et al. 1996). In pig breeding the selection for higher weight gain resulted higher incidence of some free-radical mediated diseases such as cardio-angiopathy, generally known as Mulberry heart disease (Rice \& Kennedy 1989) which may be caused by the higher levels of growth hormone, which increases the oxidative metabolism through formation of oxygen free radicals and lipid peroxidation. However, adequate antioxidant defence can compensate the oxygen free radical-mediated damages and prevent from the development of degenerative pathological events (Brambilla \& Cantafora 2004).

Purpose of present study was to investigate the differences in the extent of lipid peroxidation as measured by the amount of malondialdehyde (MDA), a meta-stable endproduct of free radical generated lipid peroxidation processes (Janero 1990), and among the antioxidant parameters the amount of reduced glutathione (GSH) and activity of glutathione peroxidase (GPx) in the liver and kidney homogenates in some pig hybrids. The other purpose was to determine correlations between all the measured parameters (lipid peroxidation and glutathione redox parameters, daily weight gain) of different hybrids.

\section{Materials and methods}

\section{Animals, feeding and samples}

Pigs (sex ratio $1: 1 ; n=10$ in each genotypes) were fattened from four hybrids: Pannon [(Hungarian Large White $\times$ Hungarian Landrace $) \mathrm{F}_{1} \times($ Pietrain $\times$ Duroc $\left.) \mathrm{F}_{1}\right]$, Hungahib-39 [(Hungarian Large White $\times$ Hungarian Landrace $) \mathrm{F}_{1} \times($ Pietrain $\times$ Hampshire $\left.) \mathrm{F}_{1}\right]$, Középtiszai [((British Large White $\times$ British Landrace $) \times$ Duroc $) \times$ terminal boar $/$ sire] and Dalland $[(($ Pietrain $\times$ Large White $) \times$ Large White $) \times$ boar/sire from a synthetic line] fed with the same growing-finishing diet (Table 1) in a self-performance (progeny) test. Nutrient content of the pelleted diet was measured according to the Hungarian Feed Code (2004). Composition of mineral and vitamin premix was given by according to the certificate of the manufacturer. Fatty acid composition of the diet (Table 2) was determined after the extraction of fat (Folch et al. 1957), and fatty acids converted to methyl esters by means of $\mathrm{BF}_{3}$ and methanol. Fatty acid 
methyl esters were analysed on an Agilent Technologies (Santa Clara, CA, USA) capillary gas chromatograph system with a SP-23804 capillary column $(30 \mathrm{~m} \times 0.25 \mathrm{~mm}$ inside diameter, $0.20 \mu \mathrm{m}$ film, Supelco, Bellefonte, PA, USA) and a flame ionisation detector. Individual fatty acids were identified based on their retention times, as assessed from a standard fatty acid mixture (Mixture Me 105, Larodan Fine Chemicals, Malmö, Sweden).

Table 1

Chemical composition of the diet

Nutrient

Dry matter ( $\mathrm{g} \mathrm{kg}^{-1}$ feed)

891.9

Crude protein $\left(\mathrm{g} \mathrm{kg}^{-1} \mathrm{feed}\right)$

192.5

Crude fat $\left(\mathrm{g} \mathrm{kg}^{-1}\right.$ feed)

24.7

Crude fibre ( $\mathrm{g} \mathrm{kg}^{-1}$ feed)

23.6

Crude ash ( $\mathrm{g} \mathrm{kg}^{-1}$ feed)

56.7

Nitrogen-free extract $\left(\mathrm{g} \mathrm{kg}^{-1}\right.$ feed)

594.4

DEs (MJ kg-1 feed)

15.21

Mineral vitamin premix (inclusion rate: $3 \%) 1000 \mathrm{~g}$ contains: vitamin A 2,300,000 IU; vitamin $D_{3}$ 470,000 IU; vitamin $\mathrm{E}$ 3333 mg; vitamin K 333 mg; thiamine 333 mg; riboflavin 700 mg; pyridoxine $333 \mathrm{mg}$; vitamin $B_{12} 3.4$ mg; nicotinamide 3.33 mg; D-Ca-panthothenate 1.67 mg; Fe 25 g; Zn 33.3 g; Mn 6.7 g; Cu 3.3 g; I 167 mg; Co 167 mg; Se 33 mg

Table 2

Fatty acid composition of the diet

\begin{tabular}{|c|c|}
\hline Fatty acid & $\mathrm{g} / 100 \mathrm{~g}$ total fatty acids \\
\hline $\mathrm{C} 12: 0$ & 0.03 \\
\hline $\mathrm{C} 14: 0$ & 0.61 \\
\hline $\mathrm{C} 15: 0$ & 0.10 \\
\hline $\mathrm{C} 16: 0$ & 17.09 \\
\hline $\mathrm{C} 16: 1 \mathrm{n} 7 \mathrm{c}$ & 0.44 \\
\hline C17:0 & 0.20 \\
\hline $\mathrm{C} 17: 1 \mathrm{n} 7 \mathrm{c}$ & 0.03 \\
\hline C18:0 & 2.35 \\
\hline C18:1 n9 c & 20.71 \\
\hline $\mathrm{C} 18: 2 \mathrm{n} 6 \mathrm{c}$ & 49.57 \\
\hline C18:3 n3 & 3.21 \\
\hline $\mathrm{C} 20: 0$ & 0.41 \\
\hline $\mathrm{C} 20: 1 \mathrm{n} 9 \mathrm{c}$ & 1.05 \\
\hline $\mathrm{C} 20: 2 \mathrm{n} 6 \mathrm{c}$ & 0.12 \\
\hline C20:4 n6 c & 1.04 \\
\hline $\mathrm{C} 20: 5 \mathrm{n} 3 \mathrm{C}$ & 0.74 \\
\hline $\mathrm{C} 22: 0$ & 0.29 \\
\hline $\mathrm{C} 22: 5 \mathrm{n} 3 \mathrm{C}$ & 0.09 \\
\hline $\mathrm{C} 22: 6 \mathrm{n} 3 \mathrm{C}$ & 1.56 \\
\hline $\mathrm{C} 24: 0$ & 0.30 \\
\hline C24:1 n9 c & 0.04 \\
\hline ESAT & 21.38 \\
\hline Emonoenoic & 22.27 \\
\hline ¿PUFA & 56.32 \\
\hline$\sum \mathrm{n} 3$ & 5.60 \\
\hline$\sum \mathrm{n} 6$ & 50.73 \\
\hline
\end{tabular}


Individual feed intake was measured daily and body weight monthly, and daily weight gain was calculated for the whole fattening period. All of the animals were slaughtered at the body weight of $100 \pm 2 \mathrm{~kg}$. Liver (lobus intermedius) and kidney (caudal part of right kidney) samples were taken at the slaughter house and stored at $-70^{\circ} \mathrm{C}$ until analyses.

\section{Biochemical analyses}

Liver and kidney homogenates were prepared with IKA Ultra Thurrax T18 homogenizer (IKA Werke, Staufen, Germany) with nine-fold volume of cold $\left(4^{\circ} \mathrm{C}\right)$ isotonic saline $(0.9 \% \mathrm{w} / \mathrm{v}$ $\mathrm{NaCl}$ ). Lipid peroxidation was measured based on the amount of malondialdehyde (MDA) in tissue homogenate by the method of Mihara et al. (1980) with some modifications. Shortly, samples were acidified with trichloroacetic acid (Carlo Erba, Rodano, Italy), colour complex of malondialdehyde was formed with 2-thiobarbituric acid (Sigma, St. Louis, USA) and measured spectrophotometrically at $535 \mathrm{~nm}$. The standard was 1,1,3,3-tetraethoxypropane (Fluka, Buchs, Switzerland). Reduced glutathione (GSH) concentration was determined with the method of Sedlak \& Lindsay (1968) based on the colour complex formation of non-protein sulfhydryl groups, which were separated by deproteinisation with trichloroacetic acid (Carlo Erba, Rodano, Italy), with Ellmann reagent (5,5'-dithiobis-2 nitrobenzoic acid; Sigma, St Louis, USA). The activity of glutathione peroxidase (GPx) was measured with the end-point direct method of Lawrence \& Burk (1976) with some modifications in the $10000 \times \mathrm{g}$ supernatant fraction (centrifugation at $10000 \times \mathrm{g}$ for $10 \mathrm{~min}$ at $4^{\circ} \mathrm{C}$ ) of the tissue homogenates. Shortly, oxidation of reduced glutathione (Sigma, St. Louis, USA) was determined spectrophotometrically after 10 min incubation at $25^{\circ} \mathrm{C}$ using cumene-hydroperoxide (Merck, Darmstadt, Germany) as cosubstrate. Reduced glutathione content and glutathione peroxidase activity were calculated to protein content of the $10000 \times \mathrm{g}$ supernatant fraction of tissue homogenates which was determined according to the method of Lowry et al. (1951) using Folin-Ciocalteu phenol reagent (Sigma, St. Louis, USA) and bovine serum albumin (Sigma, St. Louis, USA) as standard.

\section{Statistical analysis}

Statistical evaluation of the results was carried out by analysis of variance, least significant difference (LSD) test and linear regression analysis after calculating the means and standard deviations (SD) with Statistica for Windows 4.5 software (StatSoft, Inc. Tulsa, OK, USA).

\section{Results}

There were no significant differences between the two sexes in the production traits of different genotypes and biochemical parameters in any of the tissues (data not shown); therefore all of the data were calculated together.

\section{Production traits}

Initial body weight did not differ significantly among the hybrids, but the age at slaughtering was significantly different, because of the same slaughter weight and different average 
body weight gain. Slaughter age was significantly higher in Hungahib-39 hybrid, which also had the lowest average daily weight gain, as compared to Középtiszai and Dalland hybrids, which showed significantly higher average daily weight gain than the above mentioned Hungahib-39 and Pannon hybrids (Table 3).

Table 3

Some production traits of investigated pig hybrids (mean \pm SD)

\begin{tabular}{lccc}
\hline Genotype & Initial body weight, $\mathrm{kg}$ & Age at slaughtering, day & Daily weight gain, $\mathrm{g}$ \\
\hline Pannon & $28.90 \pm 1.79^{\mathrm{a}}$ & $157.00 \pm 4.96^{\mathrm{ab}}$ & $891.08 \pm 57.38^{\mathrm{b}}$ \\
Hungahib-39 & $28.10 \pm 3.00^{\mathrm{a}}$ & $162.50 \pm 7.60^{\mathrm{a}}$ & $869.98 \pm 73.40^{\mathrm{b}}$ \\
Középtiszai & $28.57 \pm 1.60^{\mathrm{a}}$ & $151.79 \pm 3.69^{\mathrm{b}}$ & $975.77 \pm 61.30^{\mathrm{a}}$ \\
Dalland & $29.85 \pm 1.95^{\mathrm{a}}$ & $152.38 \pm 3.73^{\mathrm{b}}$ & $975.98 \pm 69.15^{\mathrm{a}}$ \\
\hline
\end{tabular}

a,bDifferent superscripts in the same column mean significant difference at $P<0.05$ level

\section{Biochemical parameters}

The lipid peroxidation (expressed as malondialdehyde concentrations using the TBARS assay) was significantly higher in the liver homogenate of Középtiszai and Dalland hybrids as compared to the Pannon and Hungahib-39 hybrids. The lipid peroxidation in kidney homogenates of Dalland hybrid showed significantly higher value than in the Hungahib-39 and Középtiszai hybrids (Table 4). GSH content of liver homogenates did not show significant differences, but in kidney homogenates significantly lower GSH content was found in Középtiszai hybrid, than in the other hybrids investigated (Table 4). GPx activity was significantly higher in liver homogenate of Pannon and Hungahib-39 hybrids as compared to the Középtiszai hybrid (Table 4). Almost the same differences were found in GPx activity in kidney homogenates, where the Pannon hybrid had significantly higher enzyme activity than the Középtiszai (Table 4).

Table 4

Concentrations of malondialdehyde (MDA) and reduced glutathione (GSH) and activity of glutathione peroxidase (GPX) in liver and kidney homogenates of different pig hybrids (mean \pm SD)

\begin{tabular}{lccc}
\hline Genotype & $\begin{array}{c}\text { MDA } \\
\mu \text { mol g-1 wet weight }\end{array}$ & $\begin{array}{c}\text { GSH } \\
\mu \mathrm{mol} \mathrm{g}^{-1} \text { protein }\end{array}$ & $\begin{array}{c}\mathrm{GPx} \\
\mathrm{U} \mathrm{g}^{-1} \text { protein }\end{array}$ \\
\hline Liver homogenate & & & \\
Pannon & $4.29 \pm 1.85^{\mathrm{b}}$ & $1.11 \pm 0.32^{\mathrm{a}}$ & $1.30 \pm 0.28^{\mathrm{a}}$ \\
Hungahib-39 & $4.89 \pm 2.77^{\mathrm{b}}$ & $1.38 \pm 0.36^{\mathrm{a}}$ & $1.27 \pm 0.28^{\mathrm{a}}$ \\
Középtiszai & $7.86 \pm 3.41^{\mathrm{a}}$ & $1.34 \pm 0.74^{\mathrm{a}}$ & $0.95 \pm 0.40^{\mathrm{b}}$ \\
$\quad$ Dalland & $8.43 \pm 3.58^{\mathrm{a}}$ & $1.18 \pm 0.48^{\mathrm{a}}$ & $0.99 \pm 0.35^{\mathrm{ab}}$ \\
Kidney homogenate & & & \\
Pannon & $6.38 \pm 2.26^{\mathrm{ab}}$ & $0.93 \pm 0.31^{\mathrm{a}}$ & $1.41 \pm 0.43^{\mathrm{a}}$ \\
Hungahib-39 & $5.58 \pm 2.48^{\mathrm{b}}$ & $0.95 \pm 0.20^{\mathrm{a}}$ & $1.14 \pm 0.54^{\mathrm{ab}}$ \\
Középtiszai & $6.25 \pm 1.76^{\mathrm{b}}$ & $0.68 \pm 0.07^{\mathrm{b}}$ & $0.92 \pm 0.24^{\mathrm{b}}$ \\
Dalland & $8.11 \pm 0.75^{\mathrm{a}}$ & $0.89 \pm 0.09^{\mathrm{a}}$ & $1.13 \pm 0.26^{\mathrm{ab}}$ \\
\hline
\end{tabular}

${ }_{\mathrm{a}, \mathrm{b}}$ Different superscripts in the same column mean significant difference at $P<0.05$ level 


\section{Linear regression analysis among measured parameters}

Daily weight gain did not show significant correlation with lipid peroxidation of liver homogenate in hybrids investigated (Table 5), but close positive significant correlations were found in kidney homogenate of Pannon and Hungahib-39 hybrids (Table 5). There was no significant overall correlation for the investigated four hybrids between daily weight gain and lipid peroxidation in liver homogenate, but close positive significant correlation was found in kidney homogenate (Table 5). Daily weight gain showed close positive significant correlation with GSH content in liver homogenate in Középtiszai hybrid (Table 5), which had the second highest daily weight gain and also the highest GSH concentration in liver homogenate among the four genotypes. Daily weight gain did not show significant correlation with GSH concentration of kidney homogenate (Table 5). There was not significant overall correlation between daily weight gain and GSH content of liver homogenates, but negative significant correlation was found in the case of kidney homogenates (Table 5). Daily weight gain showed not significant and most of the hybrids negative correlation with GPx activity both in liver and kidney homogenates (Table 5). Overall correlations between daily weight gain and GPx activity in liver and kidney homogenates were negative and significant (Table 5).

Table 5

Correlations between daily weight gain and lipid peroxide or glutathione redox parameters and among lipid peroxide and glutathione redox parameters of liver and kidney homogenate in different pig hybrids

\begin{tabular}{lcccccc}
\hline Genotypes & $\begin{array}{c}\text { Daily weight } \\
\text { gain vs. MDA }\end{array}$ & $\begin{array}{c}\text { Daily weight } \\
\text { gain vs. GSH }\end{array}$ & $\begin{array}{c}\text { Daily weight } \\
\text { gain vs. GPx }\end{array}$ & $\begin{array}{c}\text { GSH } \\
\text { vs. MDA }\end{array}$ & $\begin{array}{c}\text { GPx } \\
\text { vs. MDA }\end{array}$ & $\begin{array}{c}\text { GSH } \\
\text { vs. GPx }\end{array}$ \\
\hline Liver homogenate & & & & & & \\
$\quad$ Pannon & -0.362 & -0.588 & -0.256 & 0.137 & -0.090 & $0.758^{*}$ \\
Hungahib-39 & 0.125 & 0.132 & -0.578 & -0.021 & -0.333 & 0.459 \\
Középtiszai & -0.586 & $0.652^{*}$ & -0.047 & $-0.764^{*}$ & -0.520 & 0.166 \\
Dalland & -0.416 & -0.061 & 0.178 & -0.360 & -0.493 & 0.468 \\
Overall & 0.108 & 0.127 & $-0.371^{*}$ & -0.278 & $-0.543^{* *}$ & 0.288 \\
Kidney homogenate & & & & & & \\
Pannon & $0.698^{*}$ & -0.603 & -0.445 & $-0.792^{* *}$ & -0.353 & $0.722^{*}$ \\
Hungahib-39 & $0.901^{* * *}$ & -0.362 & -0.485 & -0.278 & -0.200 & 0.522 \\
Középtiszai & -0.046 & 0.253 & -0.103 & -0.488 & -0.470 & 0.424 \\
Dalland & 0.203 & 0.626 & -0.065 & -0.080 & $-0.755^{*}$ & 0.257 \\
Overall & $0.549^{* * *}$ & $-0.362^{*}$ & $-0.357^{*}$ & $-0.390^{*}$ & -0.257 & $0.595^{* * *}$ \\
\hline
\end{tabular}

Levels of significance: ${ }^{*} P<0.05,{ }^{*} P<0.01,{ }^{* * *} P<0.001$, MDA: malondialdehyde, GSH: reduced glutathione, GPX: glutathione peroxidase

GSH content showed significant negative correlation with lipid peroxidation in liver homogenate only in Középtiszai hybrid, and close negative correlation in kidney homogenate of Pannon hybrid (Table 5). Overall correlation between GSH and lipid peroxidation in liver homogenate was negative, but not significant and negative, significant correlation was found in kidney homogenate (Table 5). GPx activity showed negative, but not significant correlation with lipid peroxidation in liver homogenates in all of the hybrids investigated (Table 5). In kidney homogenate negative correlations were found between the GPx activity and lipid peroxidation in all hybrids, where just the Dalland hybrid showed significant value (Table 5). Overall correlation coefficient between GPx activity and lipid peroxidation showed 
close negative significant value in liver, and negative, but not significant value in kidney homogenate (Table 5).

GSH content and GPx activity in liver and kidney homogenates showed close positive and significant correlation only in Pannon hybrid (Table 5). In the case of other hybrids the correlation between GSH content and GPx activity was positive, but not significant either in liver or kidney homogenates (Table 5). Overall correlation between GSH content and GPx activity in liver homogenate showed positive, but not significant value, while close positive correlation was found in kidney homogenate (Table 5).

\section{Discussion}

According to the results of Nagy et al. (2008) the self-performance test in the field and central station (progeny) test showed the same growth traits, therefore the central station test showed similar genetic differences of growing pigs than in field condition.

The results of the present study showed that MDA content, as meta-stable end product, therefore a marker of lipid peroxidation, in liver homogenate differed significantly among the hybrids. It was the highest in those genotypes, Középtiszai and Dalland hybrids, which had significantly higher daily weight gain as compared to the two others. The higher growth rate possibly increases the formation of oxygen containing free radicals and lipid peroxidation, as it was described in pigs earlier (Brambilla et al. 2001). The overall correlation coefficient of the linear regression analysis between daily weight gain and MDA content of the four hybrids showed positive, but not significant value in liver homogenate, but close positive significant correlation in kidney homogenate. It can be explained that the antioxidant defence in liver is more effective than in kidney, or MDA is excreted through the kidneys, therefore its MDA content is higher. The previous hypothesis is supported by the overall positive correlation between daily weight gain and GSH content of liver, but negative correlation in kidney. It is well known that the primary site of GSH synthesis is the liver (Shi et al. 1996) therefore it has better antioxidant defence as compared to kidney. Daily weight gain also showed positive correlation with GSH content, the co-substrate of GPx (Sarma \& Mugesh 2008), in Középtiszai hybrid, which had the highest daily weight gain among the hybrids investigated. Activity of GPx, part of the antioxidant defence system, was not significantly lower in the other hybrids with lower weight gain, which result is partly in agreement with a previous research, which showed a negative correlation between weight gain and GPx activity in pig (Lingaas et al. 1991). GPx activity in liver and kidney homogenates showed overall positive correlation with the GSH content, which was also found in our previous experiment with poultry (Balogh et al. 2007). This positive correlation can be explained based on the previous data that GPx is an enzyme with allosteric activation property by its substrates (namely hydrogen-peroxide and other oxygen containing free radicals) and co-substrate (GSH) (Perona et al. 1978). The overall correlation between GPx activity and MDA content in liver and kidney suggests that GPx eliminates oxygen containing free radicals more effectively, therefore decreases the rate of lipid peroxidation in liver more efficiently as compared to kidney.

In conclusion, the results of present study showed that daily weight gain of pig hybrids, kept at the same environmental and feeding conditions, and slaughtered at the same body weight, has effect on the formation of oxygen containing free radicals; therefore can initiate 
lipid peroxidation in liver, but not in kidney. On the other hand amount and/or activity of the glutathione redox system differed significantly only in liver, but not in kidney. It means that in kidney the antioxidant defence mechanism, in this case the glutathione redox system, can effectively inhibit the formation of oxygen containing free radicals or scavenge them even at different growth rate in pig hybrids.

The results also suggest that pigs with different growth rate require slightly different antioxidant supply during fattening to eliminate the uncontrolled rate of oxygen free radical formation. The results of present study also suggest that the physiological normal level of lipid peroxidation and glutathione redox status parameters of liver and kidney would be different in different pig genotypes.

\section{Acknowledgement}

The financial support of the Economy-Oriented Agricultural Research Project (GAK-h200509), and that of the Research Group of Animal Breeding and Hygiene of the Hungarian Academy of Sciences is gratefully acknowledged.

\section{References}

Atroshi F, Sankari S, Osterberg S, Sandholm M (1981) Variation of erythrocyte glutathione peroxidase activity in Finn sheep. Res Vet Sci 31, 267-271

Balogh K, Weber M, Erdélyi M, Mézes M (2007) Investigation of lipid peroxide and glutathione redox status of chicken conserning a high dietary selenium intake. Acta Biol Hung 58, 269-279

Brambilla G, Fiori M, Archetti LI (2001) Evaluation of the oxidative stress in growing pigs by microplate assays. J Vet Med A Physiol Pathol Clin Med 48, 33-38

Brambilla G, Cantafora A (2004) Metabolic and cardiovascular disorders in highly inbred lines for intensive pig farming: how animal welfare evaluation could improve the basic knowledge of human obesity. Ann Ist Super Sanitá 40, 241-244

Buske B, Sternstein I, Reißmann M, Reinecke P, Brockmann G (2006) Analysis of association of GPX5, FUT1 and ESR2 genotypes with litter size in a commercial pig cross population. Arch Tierz 49, 259-268

Fidanci UR, Turgay F, Zengin S, Kargin F, Celik S, Tasdemir U (2001) [The effect of genotype on the antioxidative metabolism in Angora goats]. Turk J Vet Anim Sci 25, 975-981 [in Turkish]

Folch JM, Lees M, Sloane Stanley GH (1957) A simple method for the isolation and purification of total lipides from animal tissues. J Biol Chem 226, 495-509

Hungarian Feed Code (2004) [Methods for the determination of nutrients in feeding stuffs and complete feeds]. OMMI, Budapest, Hungary, vol. 3, 101-533 [in Hungarian]

Janero DR (1990) Malondialdehyde and thiobarbituric acid-reactivity as diagnostic indices of lipid peroxidation and peroxidative tissue injury. Free Radic Biol Med 9, 515-540

Krska P, Lahucky R, Küchenmeister U, Nürnberg K, Palanska O, Bahelka I, Kuhn G, Ender K (2001) Effects of dietary organic selenium and vitamin $\mathrm{E}$ supplementation on post mortem oxidative deterioration in muscles of pigs. Arch Tierz 44, 193-201

Lawrence RA, Burk RF (1976) Glutathione peroxidase activity in selenium-deficient rat liver. Biochem Biophys Res Commun 71, 952-958

Lingaas F, Brun E, Froslie A (1991) Estimates of heritability for selenium and glutathione peroxidase levels in pigs. J Anim Breed Gen 108, 48-53

Lowry OH, Rosenbrough NJ, Farr AL, Randall RJ (1951) Protein measurement with the Folin phenol reagent. J Biol Chem 193, 265-275 
Mézes M, Szalay I, Vas E (1989) Glutathione metabolism enzymes as possible markers for goose liver selection. Proc Int Symp Current Problems of Avian Genetics, Smolenice, Slovakia, 114-118

Mihara M, Uchiyama M, Fukuzawa K (1980) Thiobarbituric acid value on fresh homogenate of rat as a parameter of lipid peroxidation in ageing, CCl4 intoxication and vitamin E deficiency. Biochem Med 23, 302-311

Nagy I, Csató L, Farkas J, Gyovai P, Radnóczi L, Komlósi I (2008) Genetic parameters of direct and ratio traits from field and station tests of pigs. Arch Tierz 51, 172-178

Perona G, Guidi GC, Piga A, Cellerino R, Menna R, Zatti M (1978) In vivo and in vitro variations of human erythrocyte glutathione peroxidase activity as result of cells ageing, selenium availability and peroxide activation. Br J Haematol 39, 399-408

Rice DA, Kennedy S (1989) Vitamin E, selenium, and polyunsaturated fatty acid concentrations and glutathione peroxidase activity in tissues from pigs with dietetic microangiopathy (mulberry heart disease). Am J Vet Res 50, 2101-2104

Sarma BK, Mugesh G (2008) Thiol cofactors for selenoenzymes and their synthetic mimics. Org Biomol Chem 6, 965-974

Sedlak I, Lindsay RH (1968) Estimation of total, protein-bound, and nonprotein sulfhydryl groups in tissues with Ellmann's reagent. Anal Biochem 25, 192-205

Shaaban G, Mézes M, Hidas A (2004) Phenotypic variation in the activities of glutathione peroxidase and their correlation with some production traits in two chicken breeds and their crosses. Arch Geflügelk 68, 211-217

Shi ZZ, Carter BZ, Habib GM, He X, Sazer S, Lebovitz RM, Lieberman MW (1996) A single mouse glutathione synthetase gene encodes six mRNAs with different $5^{\prime}$ ends. Arch Biochem Biophys 331, 215-224

Śliwa-Jóźwik A, Jóźwik A, Kołataj A (2002) Influence of exogenous glutathione (GSH), as stressfactor, on the activity of lysosome enzymes in some organs of mice. Arch Tierz 45, 307-314

Vaiman M, Chardon P, Rothschild MF (1998) Porcine major histocompatibility complex. Rev Sci Tech 17, 95-107

Virág G, Mézes M, Szendrő Z, Romvári R, Radnai I, Biróné Németh E (1996) Moderate phenotypic relationship between glutathione peroxidase activity and carcass traits in rabbits could be partially determined by genetic effect. Proc. 6th World Rabbit Congress, Toulouse, France, vol. 2, 381-384

Wachter CM, McDaniel BT, Whitlow, LW, Pettyjohn S (1999) Genetics of antioxidant activity in Holsteins and Jerseys: associations with various traits. J Dairy Sci 82 (Suppl. 1), 31

Received 31 July 2011, accepted 20 December 2011.

Corresponding author:

Miklós Mézes

email: mezes.miklos@mkk.szie.hu

Department of Nutrition, Szent István University, Páter Károly u. 1., H-2103 Gödöllő, Hungary 